\title{
AMORPHOUS SILICA BIOMINERALIZATIONS IN SCHOENOPLECTUS CALIFORNICUS (CYPERACEAE): THEIR RELATION WITH MATURATION STAGE AND SILICA AVAILABILITY
}

\author{
MARIANA FERNÁNDEZ HONAINE ${ }^{1,2,3}$, NATALIA L. BORRELLII,2,3, MARGARITA \\ OSTERRIETH ${ }^{1,2}$ and LUIS DEL RIO ${ }^{1,4}$
}

\begin{abstract}
Summary: The factors involved on the silicification process in Cyperaceae are scarcely known. In this study we analyse the effect of maturation stage and silica availability on the production of amorphous silica biomineralizations in culms of Schoenoplectus californicus. Young and senescent culms were collected from ponds with different silica availability. Two complementary methodologies (calcination and staining techniques), light and scanning electron microscopy and EDS were applied for amorphous silica analyses in plants. Quantitative data were analysed by Kruskal-Wallis and a two-way ANOVA tests. There were no significant differences between silica content of culms collected in ponds with different silica availability. Instead, silica content in senescent culms was higher than in young culms ( $F=91.43$, $P<0.01)$. Young culms only produce cone-shaped amorphous silica bodies, located in epidermal cells overlying sclerenchyma. Senescent culms produce a higher diversity of silicified cells, such as epidermal, stellate (aerenchyma) and parenchymatic cells. Silicification process in S. californicus is clearly affected by age and may act as a mechanism of structural resistance improvement. Some cells became silicified very early in the development and others may be silicified at a later stage depending on wall characteristics or rate of transpiration.
\end{abstract}

Key words: Sedge, silicophytoliths, senescence, aerenchyma, culms, ponds, SE Buenos Aires province.

\begin{abstract}
Resumen: Biomineralizaciones de sílice amorfo en Schoenoplectus californicus (Cyperaceae): su relación con el estado de maduración y la disponibilidad de sílice. Los factores involucrados en el proceso de silicificación en Cyperaceae son poco conocidos. En este estudio se analiza el efecto del estado de maduración y la disponibilidad de sílice en la producción de biomineralizaciones de sílice amorfo en tallos de Schoenoplectus californicus. Tallos jóvenes y senescentes fueron recolectados de lagunas con diferente disponibilidad de sílice. Dos técnicas complementarias (calcinación y tinción), microscopía óptica y electrónica y EDAX fueron aplicados para el análisis en las plantas. Los datos cuantitativos fueron analizados por tests de Kruskal-Wallis y ANOVA de dos vías. No hubo diferencias significativas entre el contenido de sílice en los tallos recolectados en lagunas con diferente disponibilidad de sílice. En cambio, el contenido en tallos senescentes fue mayor que en los jóvenes $(F=91,43 ; P<0,01)$. Los tallos jóvenes solo producen cuerpos silíceos cónicos, localizados en células epidérmicas asociadas al esclerénquima. En los tallos senescentes se silicifican una mayor diversidad de células, como las epidérmicas, del aerénquima y esclerénquima. El proceso de silicificación en $S$. californicus está claramente afectado por la edad y mejoraría la resistencia estructural. Algunas células se silicifican tempranamente, mientras que en otras depende de las características de la pared celular y/o de la tasa de transpiración.
\end{abstract}

Palabras clave: Junco, silicofitolitos, senescencia, aerénquima, tallos, lagunas, sudeste bonaerense.

\footnotetext{
${ }^{1}$ Instituto de Geología de Costas y del Cuaternario, Facultad de Ciencias Exactas y Naturales, Universidad Nacional de Mar del Plata, CC 722, Correo Central, 7600 Mar del Plata, Argentina.

2 Instituto de Investigaciones Marinas y Costeras (IIMyC)-Facultad de Ciencias Exactas y Naturales, Universidad Nacional de Mar del Plata- Consejo Nacional de Investigaciones Científicas y Técnicas.

${ }^{3}$ CONICET.

${ }^{4}$ Unidad Académica Mar del Plata, Universidad Tecnológica Nacional.
} 


\section{INTRODUCTION}

Biomineralizations are biogenic inorganicorganic composites, crystalline or amorphous, deposited in intracellular or extracellular spaces as the consequence of metabolic activity of organisms (Lowenstam, 1981; Osterrieth, 2004). One of the most common type of biomineralization in plants are the deposits of amorphous silica bodies $\left(\mathrm{SiO}_{2}\right.$. $\mathrm{nH}_{2} \mathrm{O}$ ) (also called phytoliths or silicophytoliths), in tissues of diverse organs (e.g., Piperno, 2006; Bauer et al., 2011). Cyperaceae sedges along with other families such as grasses, palms and Equisetaceae, are important producers of this type of biomineralization (Metcalfe, 1971; Piperno, 2006). The first studies about the presence of silicified cells in sedges date from XIX century, where Duval-Jouve (1873) and Wilczek (1892) described the "cone-shaped silica bodies" in epidermal cells overlying the sclerenchyma, in leaves, culms and fruits. Later, Mehra \& Sharma (1965) explained the development of these "silica bodies" in Eriophorum comosum Wall. ex Nees. Metcalfe (1971) described and classified these silica bodies in many species of the family, and since then, many anatomical and descriptive studies have been carried on this issue (Schuyler, 1971; Gordon-Gray et al., 1978; Ragonese et al., 1984; Ollendorf, 1992; Browning \& Gordon-Gray, 1995; Fernández Honaine et al., 2009, among others). These researches showed that the main silicified tissues are epidermal (where cone-shaped amorphous silica bodies are developed), and in a lesser degree, xylem, parenchyma and sclerenchyma.

The relation between the content of silica (measured as $\mathrm{SiO}_{2}$ ) and/or the amorphous silica biomineralizations (measured as the quantity of amorphous silica bodies or silicified cells in a tissue), and environmental and biological factors has been studied in other monocot family such as Poaceae (e.g., Jones \& Handreck, 1967; Handreck \& Jones, 1968; Sangster \& Parry, 1971; Dorweiler \& Doebley, 1997; Ma \& Takahashi, 2002; Motomura et al., 2002; Hodson et al., 2005; Massey et al., 2007). In general terms, these studies showed that silica and/or biomineralization content depends on external factors (silica availability in soils, presence of oxides, water availability, herbivore pressure) and on internal factors (genetics, type of organ or tissue, age of the organ, transpiration rate). According to studies carried on bamboos and crops, silica content in tissues increase with silica availability in soils and with the age of the organ (e.g., Motomura et al., 2002, 2004; Handreck $\&$ Jones 1968). The age, position and section of the organ, the silica content on soils and the transpiration rate are some of the most important factors involved in the distribution of the silicified cells in tissues of grasses, i.e. the formation of the amorphous silica biomineralizations (Sangster \& Parry, 1971; Motomura et al., 2004, 2006; de Melo et al., 2010; Fernández Honaine \& Osterrieth, 2012). Lastly, some studies revealed the importance of genetics regulation in the distribution of silica cells in tissues (e.g., Dorweiler \& Doebley, 1997; Yamaji et al., 2008). For example, Dorweiler \& Doebley (1997) revealed in Zea mays that the tgal locus seems to affect the number and distribution of silica cells in the epidermis, as well as where the silica is deposited. In Cyperaceae family, no studies dealing with the relation between amorphous silica biomineralization content and environmental and/ or biological factors have been found until now.

Considering the importance of phylogeny on the process of silicification and the relatively close relation between grasses and sedges, it is possible to hypothesize that the factors affecting the silicification in Poaceae apply for Cyperaceae (Hodson et al., 2005). Thus, it is expected that: 1) increasing the availability of silicic acid in the soil favor the accumulation of amorphous silica biomineralizations in the tissue, and 2) old plants accumulate more amorphous silica biomineralizations in their tissues than young ones.

In order to address to these hypotheses we analyzed young and senescent culms of a wide spread bulrush native to America continent, Schoenoplectus californicus (C.A. Mey) Soják, collected from three different aquatic environments from SE Buenos Aires province, Argentina. Schoenoplectus californicus is a hydrophyte, perennial and rhizomatous species living in marshy soils, ponds and streams, also fresh or saline water, and it is an important component of the flora of wetlands and aquatic environments (Rossi \& Tur, 1976; Tur \& Rossi, 1976).

In aquatic environments, as well as in terrestrial ones, plants have a relevant function in the biogeochemical cycle of $\mathrm{Si}$, both as agents of absorption and accumulation of silicic acid and as 


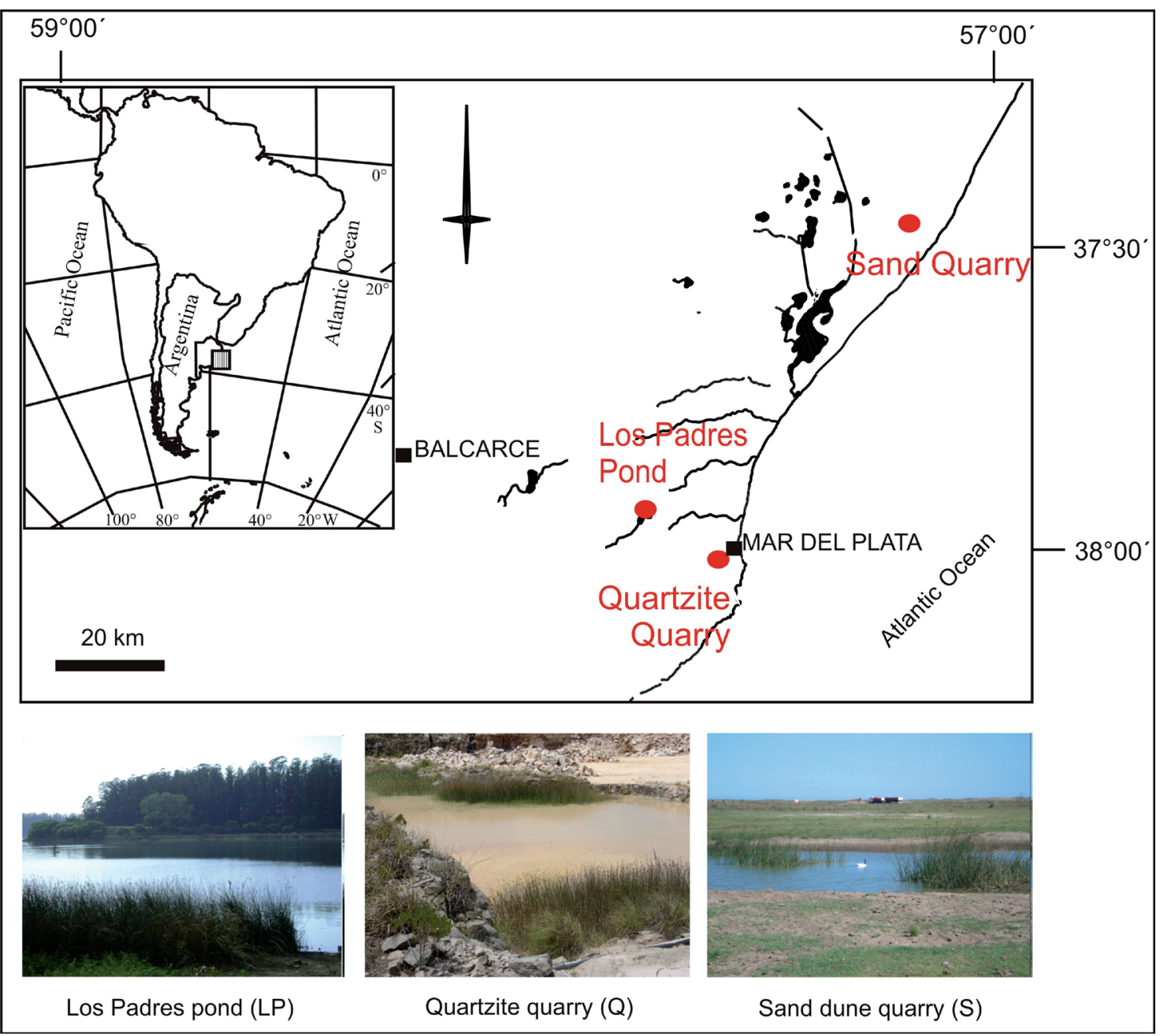

Fig. 1. Location of the three sites analyzed (circular symbols) and photographs of the environments.

sources of biogenic silica (e.g. Derry et al., 2005; Farmer et al., 2005; Struyf et al., 2007). However, there are few studies that analyze the silicification process in wetland species (Struyf et al., 2007). Previous studies in Schoenoplectus californicus showed that this species produces amorphous silica biomineralizations in fruits and culms (Schuyler, 1971; Fernández Honaine et al., 2009). The present work discusses how the production of these biomineralizations is affected by maturation stage and environmental conditions, information that may contribute to the comprehension of the biogeochemical cycle of $\mathrm{Si}$ in the areas where this species develops.

\section{Materials and Methods}

Site selection and environmental characterization

Three aquatic environments with different geomorphologic and hydric characteristics located in the SE Buenos Aires Province, Argentina, were selected for the collection of plants of Schoenoplectus californicus: 1) Los Padres Pond Natural Reserve, Gral. Pueyrredón, Buenos Aires; 2) Quartzite Quarry, Batán, Gral. Pueyrredón, Buenos Aires; 3) Sand dunes Quarry, Gral. Madariaga, Buenos Aires (Fig. 1).

Los Padres Pond Natural Reserve (37 $56^{\prime}$ S; $57^{\circ} 50^{\prime} \mathrm{W}$ ) is a natural area of $687 \mathrm{ha}$, where 319 
ha correspond to an eolic pond, surrounded by low eolic hills (Cionchi et al., 1982). The representative soils of Los Padres Basin are Typical Argiudolls, which were originated from eolian sediments during the latest arid cycle of the late Pleistoceneearly Holocene (INTA, 1989). These soils are highly developed and their texture is silt loam, with silt $(55-70 \%)$ and clay $(20-30 \%)$ fractions being the most representative (Borrelli et al. 2008). In Los Padres Pond, the hydromorphic soils were originated from reworked loess of alluvial origin, and their texture is sandy loam to silty (Cionchi et al., 1982). The pond has only one inflow stream, Los Padres Stream, and one outflow stream, La Tapera Stream. In surface waters, the $\mathrm{pH}$ is alkaline with a mean value of $9.27 \pm 0.04$, the conductivity varies from 961 to $1015 \mu \mathrm{S} / \mathrm{cm}^{2}$, with a mean value of $994 \pm 25 \mu \mathrm{S} / \mathrm{cm}^{2}$, and the salinity is about $0.5 \mathrm{ppt}$ (Borrelli et al. 2012). The vegetation of the border of the pond is characterized by Typha latifolia, Polygonum hydropiperoides, Alternanthera philoxeroides, Bidens laevis, Mikania parodii and Ludwigia sp., among others.

The Quartzite Quarry, Batán city, (3830' S, $57^{\circ}$ $\left.45^{\prime} \mathrm{W}\right)$ constitute anthropogenic diggings $40 \mathrm{~m}$ in depth on average, made for quartzite extraction (Fig. 1). The soils are Tecnosols (IUSS-WRB, 2007), have an incipient development and are characterized by a depth that ranges between some millimeters to about $10 \mathrm{~cm}$. The profiles that developed AC and CA horizons have sandy and sandy-silt textures, respectively (Osterrieth et al., 2012). The shallow depth, coarse texture and lax structure cause these soils to have low hydric retention and rainwater is the main source of water for plants. As a consequence of the mineral exploitation, different waterbodies developed (del Río et al., 2005). These small ponds are temporary, have a variable depth and they are fed by rainwater. The pond selected for the study also receives water from the washing of the quartzite material extracted, thus the availability of silica in these diggings is greater. The waters are slightly alkaline, being the $\mathrm{pH}$ range from 8.23 to 9.18 , and the salinity is close to 0 (zero) (del Rio et al., 2005). Once the extraction activity is ended, typical aquatic vegetation, such as Juncus spp. and S. californicus, develops in these waterbodies.

The Sand dune Quarry $\left(37^{\circ} 23^{\prime} \mathrm{S}, 57^{\circ} 05^{\prime} \mathrm{W}\right)$ is located in a coastal sector of Buenos Aires province,
Argentina, where sand is extracted for commercial use (Fig. 1). The soils are Arenosols (IUSS-WRB, 2007) that have evolved from coastal dunes. These soils have a high permeability and their texture is sandy loam (IUSS-WRB, 2007) with the fine sands as the representative fraction (Fernández Montoni, 2011). As a consequence of the extraction activity some semipermanent and permanent ponds have been developed. These ponds are fed by rainwater and ground water; $\mathrm{pH}$ ranges from 8.4 to 8.83 , being slightly alkaline waters, the conductivity is about $338 \mu \mathrm{S} / \mathrm{cm}^{2}$ and salinity is around $0.2 \mathrm{ppt}$ (Fernández Montoni, 2011). In this site, plants were collected from two different ponds (S1 and S2).

\section{Si content in surface waters}

Several surface water samples of the different ponds were collected along two years, including the moment of the vegetation sampling (20082009). The collection and preservation of water samples were made following the standard methods according to American Public Health Association (1998). Surface water samples were filtered through $0.45 \mu \mathrm{m}$ pore size membrane filters of cellulose nitrate and silica concentration $\left(\mathrm{SiO}_{2}\right)$ was determined by means of silicomolybdate method (American Public Health Association, 1998).

\section{Plant collection}

In each of the three sites selected, ten culms of Schoenoplectus californicus were collected: five young culms (green flowering, with flowers or with immature or mature fruits) and five senescent culms (with completely mature and disperse fruits). Culms were measured and between 1.5 and $3 \mathrm{~g}$. from each one were sampled, including basal, median and apical sections.

\section{Analyses of the amorphous silica content}

Culms were subjected to the calcination technique sensu Labouriau (1983). After this treatment ashes mainly compound by the amorphous silica biomineralizations produced along the plant life, were obtained. This technique destroys the organic matter, dissolves calcium crystals and releases amorphous silica biomineralizations.

The culms were first placed in an ultrasound bath for 15-20 min and washed with distilled water to remove mineral contaminants. The samples were 
dried at $56^{\circ} \mathrm{C}$ for $24 \mathrm{~h}$, weighted and charred at $200^{\circ} \mathrm{C}$ for $2 \mathrm{~h}$. Later, they were boiled in a $5 \mathrm{~N} \mathrm{HCl}$ solution for $10 \mathrm{~min}$, washed with distilled water and filtered with ashless filter paper, until no more chloride ions were detected. Finally, the samples were ignited at $760^{\circ} \mathrm{C}$ for $3 \mathrm{~h}$ (Labouriau, 1983). The final ashes were weighted and amorphous silica content was calculated as a percentage of dry weight. The ashes were mounted with immersion oil and were observed and described with a Zeiss Axiostar plus microscope at 400× magnification. Microphotographs were taken with a digital camera Canon Powershot G10. Between 200 and 250 particles were counted in each slide and the morphotypes were described according to Fernández Honaine et al. (2009) and Madella et al. (2005). The relative frequency of each morphotype in each sample was calculated. Some samples were coated in gold and observed by a scanning electron microscope (JEOL JSM-6460 LV, Japan) at Universidad Nacional de Mar del Plata, Argentina. The semi-cuantitative composition of the biomineralizations was analyzed by x-ray Energy Dispersive Spectroscopy (EDS) investigations. The system used was an EDAX Genesis XM4 - Sys 60, equipped with Multichannel Analyzer EDAX mod EDAM IV, Sapphire Si (Li) detector and super ultra-thin Window of Be, and EDAX Genesis version 5.11 software.

\section{Analyses of the distribution of the silicified cells in the tissues}

Since calcination technique destroys organic matter and releases amorphous silica biomineralizations, it is difficult to identify their location in tissues. For this reason, a staining methodology was used as a complement of the analyses.

Cross sections of young and senescent culms were carried on by hand. The material was cleared with $50 \%(\mathrm{w} / \mathrm{v})$ sodium hypochlorite, dehydrated in an ethanol series and then stained with phenol crystals. Phenol crystals stained silica cells with a rose colour (Johansen, 1940). Then the stained fragments were mounted with immersion oil and observed with a Zeiss Axiostar plus microscope at $400 \times$ magnification.

\section{Data analyses}

Mean and standard deviation of $\mathrm{Si}$ content in surface water in the three sites analyzed were calculated. Differences between groups of data were tested by a Kruskal-Wallis test and a nonparametric multiple comparison test, since normality and homoscedasticity assumptions were not achieved (Zar, 1984).

Values of amorphous silica content of young and senescent culms collected in the three study sites were subjected to a two-way ANOVA test. The two factors analyzed were age (young/senescent) and collection site (Los Padres pond, Quartzite quarry, Sand quarry).

\section{Results}

\section{Si content in surface waters}

$\mathrm{Si}$ content (measured as $\mathrm{SiO}_{2}$ ) ranged between 0.9 and 47.4 mg.L $\mathrm{L}^{-1}$ (Fig. 2A). In descending order, the average values of silica content were: 27.4 $\pm 18.7 \mathrm{mg} . \mathrm{L}^{-1}$ (Quartzite quarry, Q); 6.5 \pm 0.2 mg. $\mathrm{L}^{-1}$ (waterbody of the Sand quarry, S1); $4.3 \pm 1.9$ mg. $\mathrm{L}^{-1}$ (Los Padres pond, LP) and $1.4 \pm 0.5 \mathrm{mg} . \mathrm{L}^{-1}$ (other waterbody of the Sand quarry, S2) (Fig. 2A).

The Kruskal-Wallis test carried on the Si content values showed significant differences between sites of collection $(\mathrm{H}=17.17, \mathrm{p}=0.0006)$. The multiple comparison test made a posteriori showed significant differences between Quartzite quarry and Sand quarry S2 $(\mathrm{Z}=3.86, \mathrm{p}=0.0006)$ and between Quartzite quarry and Los Padres pond $(\mathrm{Z}=2.92, \mathrm{p}=0.0204)$ (Fig. 2A).

\section{Amorphous silica content in culms}

The values of amorphous silica content obtained from ashes ranged between 5.38-12.65\% dry weight for senescent culms and $1.05-3.5 \%$ for young culms (Fig. 2B). The two-way ANOVA test showed that there are significant differences in the silica content between young and senescent culms. Instead, there are no significant differences between the amorphous silica content in culms collected from sites with different silica availability (Table 1).

\section{Anatomical description of the culms}

In cross section, the culms have a uniseriate epidermis, composed by cells of rectangular section and a thin cuticle (Fig. 3A-C). The epidermal cells associated to sclerenchyma strands contain the typical amorphous silica biomineralizations 
Bol. Soc. Argent. Bot. 48 (2) 2013

A

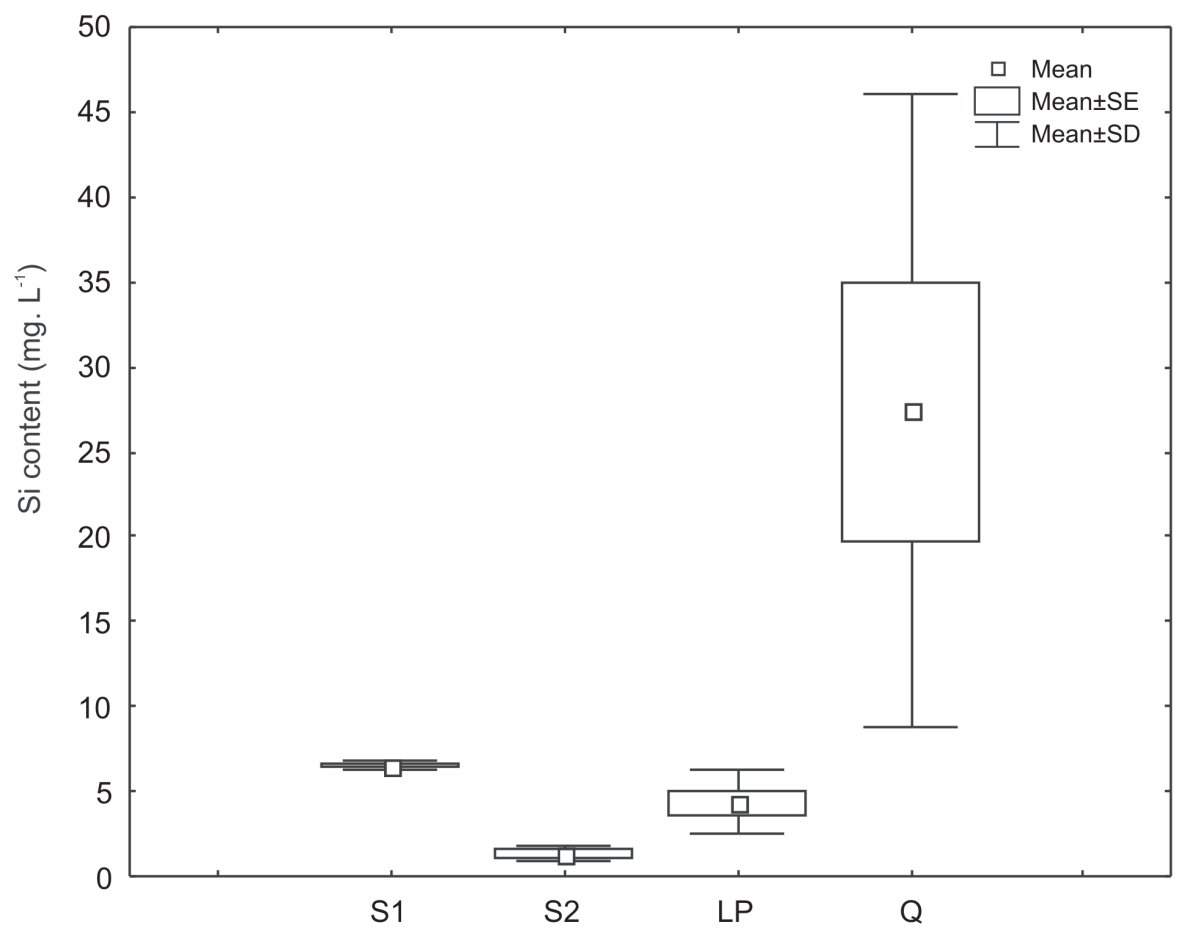

B

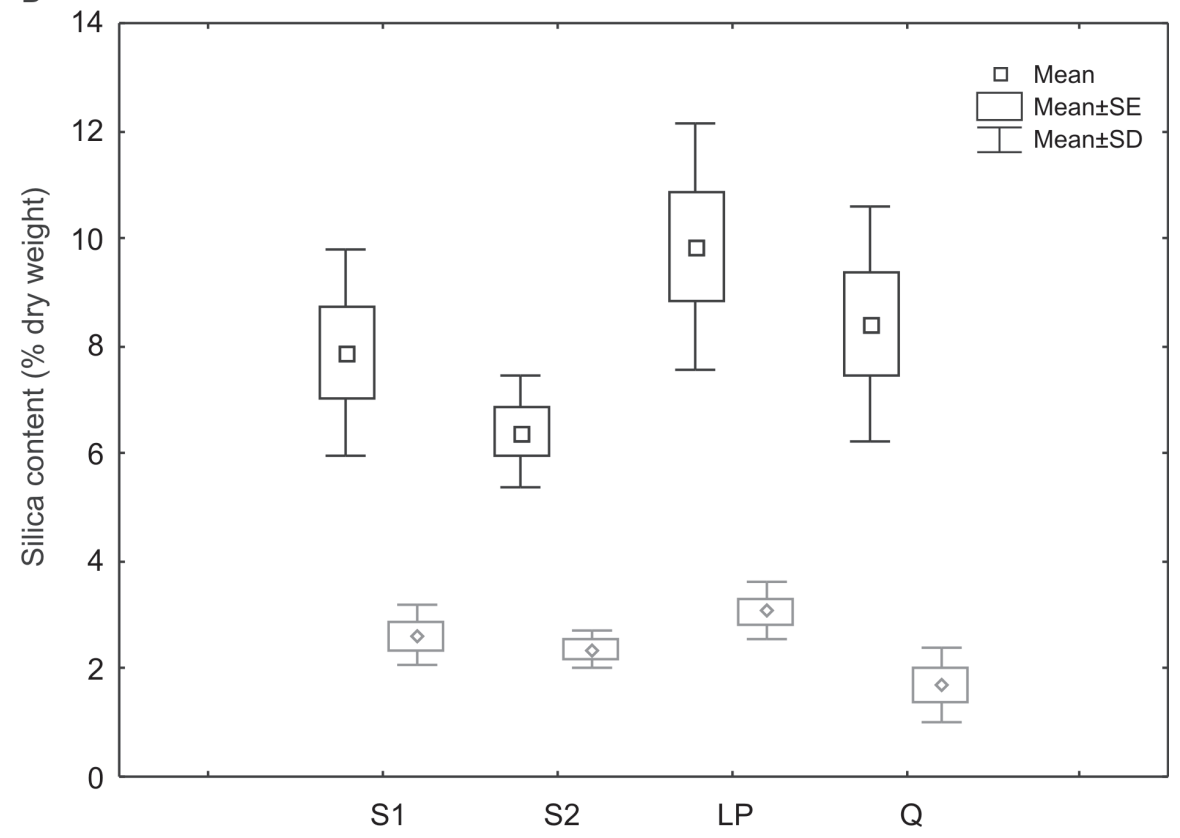

Fig. 2. A: Mean, standard error and standard deviation of Si content $\left(\mathrm{mg}^{\mathrm{L}} \mathrm{L}^{-1}\right)$ in surface water of the three sites studied. B: Mean, standard error and standard deviation of amorphous silica content of young (grey bars) and senescent culms (black bars) collected from the three sites. S1 and S2: Sand quarries; LP: Los Padres pond; Q: Quartzite quarry. 
Table 1. Two-way ANOVA test of amorphous silica content of young and senescent culms (age factor) collected in Los Padres pond, Sand quarry ponds and Quartzite quarry pond (site collection factor).

\begin{tabular}{|lcccccc|}
\hline \multicolumn{1}{c}{ Source of variation } & Sum of Squares & Degrees of freedom & Mean square & F & p(F) \\
\hline Intercept & 857.47 & 1 & 857.47 & 334.93 & 0 \\
Age & 234.08 & 1 & 234.08 & 91.43 & $0.00^{*}$ \\
Site collection & 20.16 & 3 & 6.72 & 2.62 & 0.07 \\
Age $x$ site & 7.11 & 3 & 2.37 & 0.92 & 0.44 \\
Error & 61.44 & 24 & 2.56 & & \\
\hline
\end{tabular}

*Significant differences at $P<0.01$.

(cone shaped phytoliths, $c p$ in Fig. 3B, C). The chlorenchyma consists of three layers of rectangular cells arranged as palisade tissue ( $p p$ in Fig. 3A). Ground parenchyma ( $t p$ in Fig. 3A, D) consists of two-three layers of isodiametric cells and collateral vascular bundles are embedded in this tissue. Vascular bundles are enclosed by a sheath composed of one layer of circular parenchymatic cells, and one layer of sclerenchyma at the xylem end ( $v$ in Fig. 3A). The air cavities consist of stellate cells (aerenchyma tissue) and are bounded by ground parenchyma cells (in Fig. 3A, D). Some of the parenchymatic cells that surround the external side of the air cavities have thickened cell walls (Fig. 3D, E).

The anatomy between young and senescent culms is similar, except for the ground parenchyma. In senescent culms the number of cells with thickened walls around the aerenchyma increases from one to two or three layers (Fig.3A, D).

\section{Morphological description of the amorphous silica biomineralizations (phytoliths) and their location in tissues}

Between $90-100 \%$ of the total of the biomineralizations observed in the ashes of young culms corresponded to the typical cone shape phytolith (Table 2, Fig. 4 A, B). These cones are located in the epidermal cells associated to schlerenchyma tissue, as it was observed in the cross sectioned culms analyzed (Fig. 3 A-D).

In the ashes of senescent culms, cones accounted for $50-70 \%$ of the total with other phytolith morphologies also present (Table 2). These other morphologies included silica skeletons composed by diverse type of cells (Fig. 4D), polyhedrical phytoliths (Fig. 4E), lobate phytoliths (Fig. 4 G, H), xylem and elongate phytoliths. The analyses carried on by x-ray Energy Dispersive Spectroscopy (EDS) on the phytolith morphologies clearly showed the silicon composition of them (Fig. 4 C, F, I). The study of the cross sectioned and stained culms showed that the lobate phytolith structures observed in ashes of senescent culms (Fig.4 G, H) derived from the silicification of the typical stellate cells of the aerenchyma tissue (Fig. 3 D). In the parenchyma with thickened cell walls associated to the air cavities and surrounding the internal vascular bundles, there were cells with the lumen silicified (Fig. 3 D) which resembled the polyhedrical phytoliths described in the ashes (Fig. 4 E). The elongate phytoliths are probably derived from fibers, which are commonly observed surrounding the vascular bundles and below epidermis (Fig. $3 \mathrm{~A}$ ).

These results showed that senescent culms had a higher diversity of amorphous silica biomineralizations, i.e. a higher diversity of cells that were silicified, and included at least three types of tissues.

\section{Discussion}

Amorphous silica content in culms and silica availability

Except for the values obtained for Quartzite quarry, the Si content registered in surface waters corresponds with the values obtained by the typical Pampean ponds (between 0.1 and $8 \mathrm{mg} . \mathrm{L}^{-1}$, depending of the season since $\mathrm{Si}$ content have a strong biological control) (Miretzky et al., 2001, 2002; Borrelli et al., 2012). The higher values for the Quartzite quarry are due to the extraction activity of the site. The pond studied receives water from rain but also from the washing of the 
Bol. Soc. Argent. Bot. 48 (2) 2013
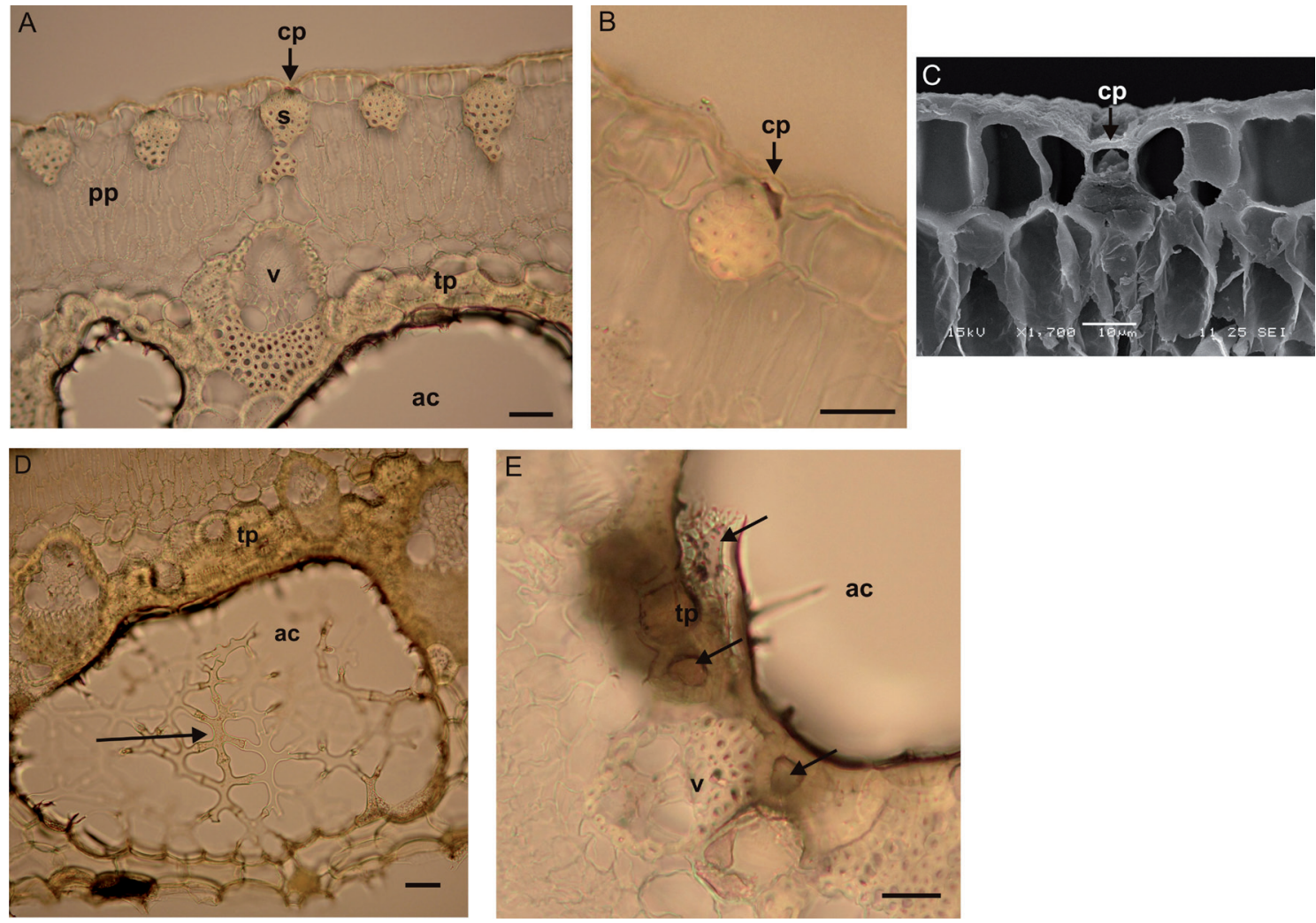

Fig. 3. Cross sectioned samples of senescent culms of Schoenoplectus californicus after phenol staining. A: General view of the main tissues: $p p$ : parenchyma arranged as palisade tissue, s: sclerenchyma strand, $v$ : vascular bundle, tp: parenchyma with thicked cell walls, ac: air cavity, $c p$ : cone shaped phytolith. B-C: Detail of the cone shaped phytoliths $(c p)$ located within epidermal cells associated to sclerenchyma strands, observed under light microscopy (B) and SEM (C). D: Air cavities showing the typical lobate cells with silica depositions (arrow). E: Parenchymatic cells with thickened walls $(t p)$ showing amorphous silica depositions (arrows). Bars: $40 \mu \mathrm{m}$ (A, D, E), $20 \mu \mathrm{m}(\mathrm{B}), 10 \mu \mathrm{m}(\mathrm{C})$.

Table 2. Relative frequency of the morphologies of the amorphous silica biomineralizations (phytoliths) observed in the ashes of young and senescent culms of S. californicus collected in the three study sites.

\begin{tabular}{|c|c|c|c|c|c|c|c|c|}
\hline \multirow{3}{*}{$\begin{array}{l}\text { Phytolith } \\
\text { morphologies }\end{array}$} & \multicolumn{8}{|c|}{ Study site } \\
\hline & \multicolumn{2}{|c|}{ Sand quarry pond 1} & \multicolumn{2}{|c|}{ Sand quarry pond 2} & \multicolumn{2}{|c|}{ Quartzite quarry } & \multicolumn{2}{|c|}{ Los Padres pond } \\
\hline & Young & Senescent & Young & Senescent & Young & Senescent & Young & Senescent \\
\hline $\begin{array}{l}\text { Cone shape } \\
\text { phytolith }\end{array}$ & $96,76 \pm 3,04$ & $52,72 \pm 11,55$ & $98,98 \pm 1,11$ & $67,75 \pm 9,04$ & 100 & $56,93 \pm 18,6$ & $93,09 \pm 5,14$ & $72,71 \pm 22,5$ \\
\hline Polyhedrical & $0,62 \pm 0,74$ & $5,53 \pm 0,54$ & $0,29 \pm 0,25$ & $5,36 \pm 3,05$ & 0 & $5,78 \pm 3,73$ & $2,36 \pm 2,9$ & $14,23 \pm 8,13$ \\
\hline Lobate & 0 & $8,11 \pm 2,37$ & 0 & $2,80 \pm 3,45$ & 0 & $10,54 \pm 9,27$ & 0 & $1,99 \pm 1,8$ \\
\hline Elongate & 0 & $6,86 \pm 1,35$ & 0 & $4,60 \pm 6,72$ & 0 & $6,42 \pm 4,47$ & 0 & $8,21 \pm 13,34$ \\
\hline Xylem & 0 & $5,41 \pm 1,75$ & 0 & $5,05 \pm 4,67$ & 0 & $5,95 \pm 3,96$ & $0,34 \pm 0,29$ & $0,15 \pm 0,27$ \\
\hline $\begin{array}{l}\text { Stomatal } \\
\text { complexes }\end{array}$ & 0 & $0,76 \pm 0,28$ & 0 & $0,32 \pm 0,73$ & 0 & 0 & 0 & 0 \\
\hline $\begin{array}{l}\text { Silica } \\
\text { skeletons }\end{array}$ & $2,62 \pm 2,41$ & $20,60 \pm 8,41$ & $0,73 \pm 0,98$ & $14,11 \pm 3,81$ & 0 & $14,38 \pm 2,96$ & $4,22 \pm 2,43$ & $2,71 \pm 2,13$ \\
\hline
\end{tabular}

Values are means \pm standard deviation of three samples. 

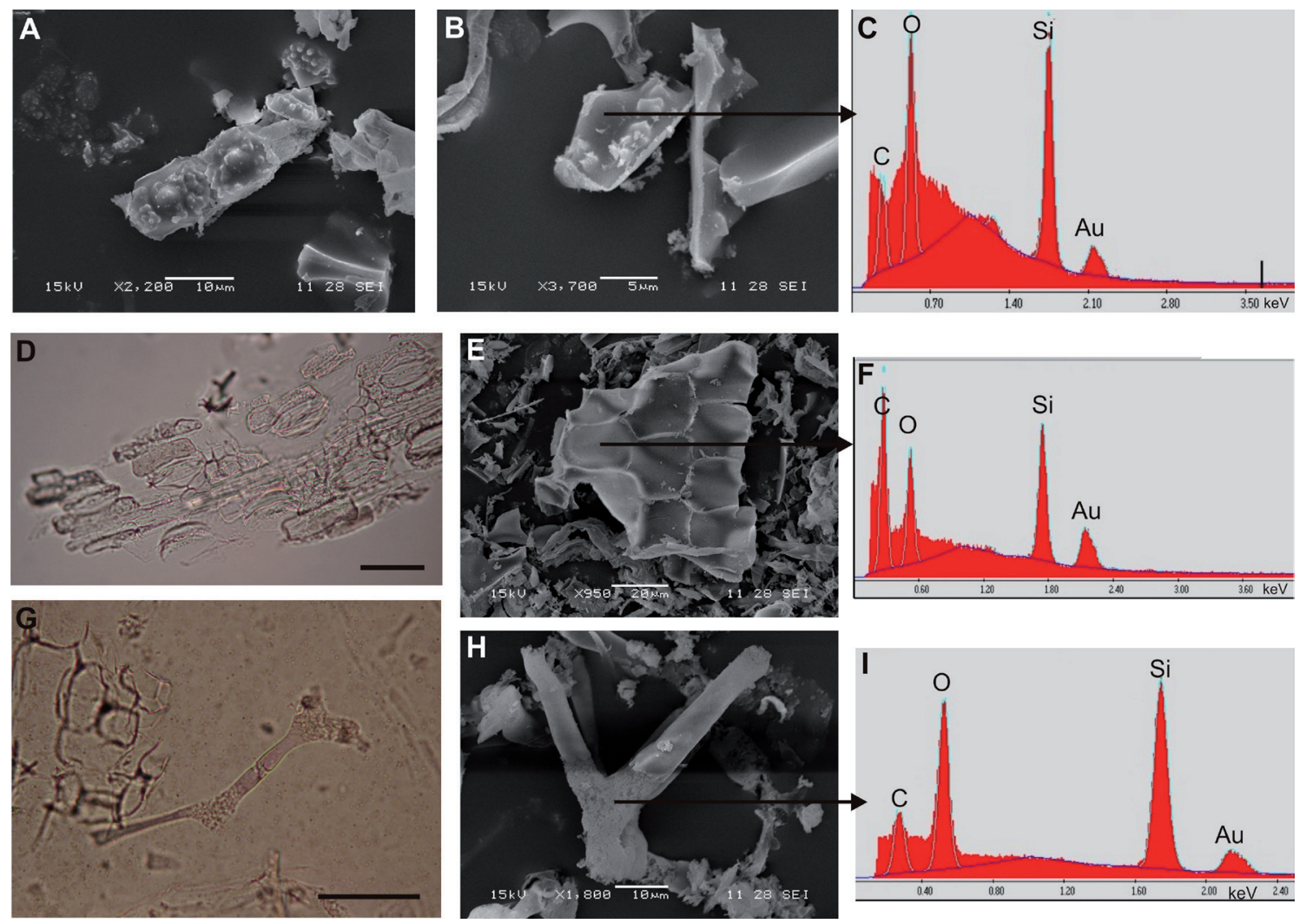

Fig. 4. Microphotographs of the amorphous silica biomineralizations obtained after calcination technique and EDAX analyses. A, B, E, H: Electron microphotographs obtained from ashes. D, G: Microphotographs obtained from ashes observed by light microscope. C, F, I: EDAX analyses. A, B: Cone shaped phytoliths. C: EDAX analyses of cone shaped phytolith. D: Silica skeletons which include stomatal complexes and elongate phytoliths. E: Polyhedrical phytoliths. F: EDAX analyses on polyhedrical phytoliths. G, H: Lobate phytoliths derived from aerenchyma cells. I: EDAX analyses on lobate phytoliths. Bars: $40 \mu \mathrm{m}(\mathrm{D}), 30 \mu \mathrm{m}(\mathrm{G})$.

quartzite material extracted. Through this washing an important quantity of fine and siliceous material is discharged into the pond, leading to the $\mathrm{Si}$ enrichment of the water. Besides the differences in the Si content in surface waters, amorphous silica content of culms collected in different sites was not significantly different. These results would reflect that the range of silica content in surface water included in the study was not sufficient to cause differences in plant silica content. A similar result has been obtained for Spartina anglica by Bakker et al. (1999), who did not find changes in tissue silica content when soils were enriched with silica. A second explanation for the lack of differences would be that silica accumulation in this species is not affected by silica availability in water.

\section{Amorphous silica content and culm age}

Amorphous silica content in S. californicus culms is clearly affected by age, as it was shown in the results, where senescent culms had the higher percentages measured as dry weight. As plant grows, silica (in the form of silicic acid) is continuously absorbed by roots and transported to the organs, where it is deposited by transpiration (e.g., Ma \& Takahashi, 2002). Since it is not remobilized once it is deposited, older tissues or organs accumulate more silica than young tissues, as well as occurs in grasses (Handreck \& Jones, 1968; Ma \& Takahashi, 2002; Motomura et al., 2002).

Which cells are to be silicified as plants grows? This study showed that the typical cone shaped phytoliths developed in the epidermal cells seem 
to be formed at an early stage, since they are practically the only morphology found in the young culms of Schoenoplectus californicus. At an older stage, stellate cells belonging to aerenchyma, polyhedrical cells from the parenchyma, fibers and xylem became silicified. The presence of silicified xylem and/or aerenchyma has been observed in leaves of other sedges; however no relation with the age of the organ was made (Gordon-Gray et al., 1978; Fernández Honaine et al., 2009). Considering that this species grows in an aquatic environment and it experiences some hydrodynamics forces higher than a terrestrial plant, it is likely that it develops some strategy to improve the structural resistance, for instance the silicification of the aerenchyma or parenchyma (Gordon-Gray et al., 1978; Prychid \& Rudall, 1999).

Which are the conditions that favor the silicification of these cells?: a thinner wall or the absence of secondary deposition and the localization of the areas where transpiration is higher seem to be relevant in this aspect. As it occurs in grasses with the "typical silica short cells", the development of the cones of sedges probably occur independently of external or internal factors and at a young stage of maturation of the organ (culm in our case) (Motomura et al., 2000, 2004, 2006). Instead, the silicification of stellate cells may be a consequence of a thinner wall, as it probably occurs in bulliforms cells of grasses (Sangster, 1970; Fernández Honaine \& Osterrieth, 2012). Also if amorphous silica deposition is driven by transpiration process (Sangster \& Parry, 1971; Ma \& Takahashi, 2002), it is likely that aerenchyma cells, which are in contact with numerous air spaces and as a consequence may have a higher loss of water, produce high quantities of amorphous silica biomineralizations (Taiz \& Zeiger, 2002). Lastly, the silicification of parenchymatic cells located at the edge of the air cavities may act as a reinforcing mechanism, avoiding the collapse of the air cavities.

\section{Amorphous silica biomineralizations} (silicophytoliths) and the Si biogeochemical cycle

The knowledge and understanding of silica biogeochemistry is important for the global biogeochemical cycles, since it is linked to the global carbon cycle by marine organisms (diatoms, radiolarians, sponges) (Tréguer et al., 1995). Although several studies focused on the marine silica cycle, the interest in the terrestrial silica cycle has recently begun to increase, since much of the reactive Si reaching the oceans has undergone prior biological cycling on the continents (Conley, 2002; Derry et al., 2005). In the study area, phytoliths represent an important fraction of the soils mineralogy, about $40 \%$ in the mollic epipedons, so they represent an important source of biogenic silica to the waterbodies through the erosion processes. While the silica cycle is strongly dominated by diatoms in wetlands, some studies were focused on the role of phytoliths of the terrestrial ecosystems in the waterbodies (Cary et al., 2005; Struyf et al., 2005; Borrelli et al., 2012). In Los Padres pond, previous studies have shown that diatoms and phytoliths of the surrounding soils constitute an important pool of reactive silica. Phytoliths produced by macrophytes could not been observed in suspension or in the bottom sediments, what could be explained by dilution effects or higher dissolution rates in relation with alkaline $\mathrm{pH}$ of the surface waters and/or lower silicification degree (Borrelli et al., 2012). Because of that it is important to know the process of silicification in vegetal aquatic communities as they contribute to complete the knowledge about the sources of reactive silica to the wetlands and oceans, and the global $\mathrm{Si}$ biogeochemical cycle.

\section{Conclusions}

Schoenoplectus californicus produces amorphous silica biomineralizations according to the phenological stage, increasing the proportion of silicified tissue at older age, probably in relation to the structural needs associated to the functions of the biomineralizations. Two groups of cells could be described: the ones that are silicified early in the development (cone shape phytoliths) and the ones that under some circumstances, such as maturation of the plant, thickness of the wall or transpiration rate became silicified (stellate cells, parenchymatic cells). It is noteworthy that silica content in culms was not affected by variations in silica availability in water; however, the inclusion of a wider range of silica availability in surface waters should be test in the future so as to corroborate these results. Finally, we can conclude that what we have observed 
on sedges could resemble to what happen in grasses, in relation to the effect of senescence and the distribution of silicified cells in tissues, but not in relation to silica availability. This work contributes to the comprehension of global silica biogeochemical cycle, and particularly the silica cycle in wetlands.

\section{Acknowledgements}

To Canteras Yaraví S.A. and Arenera Querandí. Financial support was provided by Agencia Nacional de Promoción Científica y Tecnológica, Ministerio de Ciencia y Técnica (PICT 18712010, PICT 2036-2010) and Universidad Nacional de Mar del Plata (EXA 551/11).

\section{BibLIOGRAPHY}

APHA-AWWA-WPFC (American Public Health Association-American Water Works AssociationWater Pollution Control Federation). 1998. Keys to soil taxonomy. 23rd edition. APHA, Washington, DC, USA.

BAKKER, N.V.J., M.A. HEMMINGA \& J. VAN SOELEN. 1999. The relationship between silicon availability, and growth and silicon concentration of the salt marsh halophyte Spartina anglica. Plant and Soil 215: 19-27.

BAUER, P., R. ELBAUM \& I.M. WEISS. 2011. Calcium and silicon mineralization in land plants: Transport, structure and function. Plant Science 180: 746-756.

BORRELLI, N., M. OSTERRIETH \& J. MARCOVECCHIO. 2008. Interrelations of vegetal cover, silicophytolith content and pedogenesis of Typical Argiudolls of the Pampean Plain, Argentina. Catena 75: 146-15.

BORRELLI, N., M. OSTERRIETH, A. ROMANELLI, M.F. ALVAREZ, J.L. CIONCHI \& H. MASSONE. 2012. Silica biomineralizations and their implication in soil and lagoon biogeochemistry in the southeastern of the Buenos Aires province, Argentina. Environ. Earth Sci. 65: 469-480.

BROWNING, J. \& K.D. GORDON-GRAY. 1995. Studies in Cyperaceae in southern Africa 26: glume epidermal silica deposits as a character in generic delimitation of Costularia and Cyathocoma as distinct from Tetraria and other allies. S. Afric. J. Bot. 61: 66-71.

CARY, L., A. ALEXANDRE, J.D. MEUNIER \& J.L. BOEGLIN. 2005. Contribution of phytoliths to the suspended load of biogenic silica in the Nyong basin rivers (Cameroon). Biogeochemistry 74: 101-114.

CIONCHI, J., E. SCHNACK, J. ALVAREZ, E. BOCANEGRA, J. BOGLIANO \& J.L. DEL RÍO. 1982. Caracterización hidrogeológica y físicoambiental preliminar de la Laguna de Los Padres, Partido de General Pueyrredón, provincia de Buenos Aires. CGCyC-MGP, Mar del Plata, Argentina.

CONLEY, D. J. 2002. Terrestrial ecosystems and the global biogeochemical silica cycle. Global Biogeoch. Cycles 16:1121-1129.

DE MELO, S.P., F.A. MONTEIRO \& F.D. DE BONA. 2010. Silicon distribution and accumulation in shoot tissue of the tropical forage grass Brachiaria brizantha. Plant and Soil 336: 241-249.

DEL RÍO, J.L., M. CABALLÉ, J.C. MALLO, M.L. OSTERRIETH, E. KIRILOVSKY, N. DENISIENIA, D. MUNTZ, S.G. DE MARCO, M.J. BO, V. BERNAVA LABORDE, J. MARTÍNEZ ARCA, A. LÓPEZ DE ARMENTIA, N. BORRELLI, M. FERNÁNDEZ HONAINE \& F. ALVAREZ. 2005. Estrategias de recuperación de áreas degradadas por explotaciones mineras a cielo abierto en el Partido de General Pueyrredón, Provincia de Buenos Aires: sus posibilidades de restauración, reparación o rehabilitación productivas. Final Technical report, Proyect 553/04. Comisión de Investigaciones Científicas, Bs. As., Argentina.

DERRY, L., A. KURTZ, K. ZIEGLER \& O. CHADWICK. 2005. Biological control of terrestrial silica cycling and export fluxes to watersheds. Nature 433: 728-73.

FARMER, V.C., E. DELBOS \& J.D. MILLAR. 2005. The role of phytolith formation and dissolution in controlling concentrations of silica in soil solutions and streams. Geoderma 127: 71-79.

DORWEILER, J.E. \& J. DOEBLEY. 1997. Developmental analysis of Teosinte glume architecture: a key locus in the evolution of maize (Poaceae). Amer. J. Bot.84: 1313-1322.

DUVAL-JOUVE, M.J.1873. Sur une forme de cellules épidermiques qui paraissent propres aux Cypéracées. Bull. Soc. Bot. Fr. 20: 91-95.

FERNÁNDEZ HONAINE, M. \& M. OSTERRIETH. 2012. Silicification of the adaxial epidermis of leaves of a panicoid grass in relation to leaf position and section and environmental conditions. Plant Biol. 14: 596-604.

FERNÁNDEZ HONAINE, M., A. ZUCOL, M. OSTERRIETH. 2009. Phytolith analysis of Cyperaceae from the Pampean Region, Argentina. Austr. J. Bot. 57: 512-523.

FERNÁNDEZ MONTONI, M.V. 2011. Análisis de la evolución de la vegetación en canteras de áridos de dunas costeras del partido de Gral. Madariaga, provincia de Buenos Aires, Argentina. Graduation 
thesis, FCEyN, Universidad Nacional de Mar del Plata, Mar del Plata, Buenos Aires, Argentina.

GORDON-GRAY K.D., L. VAN LAREN \& V. BANDU. 1978. Silica deposits in Rhynchospora species (Cyperaceae). Proc. Electron Microscopy Soc. South. Afric. 8: 83-84.

HANDRECK, K.A. \& L.H.P. JONES.1968. Studies of silica in the oat plant. IV. Silica content of plant parts in relation to stage of growth, supply of silica, and transpiration. Plant and Soil 29: 449-459.

HODSON, M.J., P.J. WHITE, A. MEAD \& M. R. BROADLEY. 2005. Phylogenetic variation in the silicon composition of plants. Ann. Bot. 96: 1027-1046.

INTA. 1989. Mapa de suelos de la Provincia de Buenos Aires, E 1:500000. Instituto Nacional de Tecnología Agropecuaria (INTA), Argentina.

IUSS Grupo de Trabajo WRB. 2007. Base Referencial Mundial del Recurso Suelo. Primera actualización 2007. Informes sobre Recursos Mundiales de Suelos No. 103. FAO, Roma.

JOHANSEN, D.A.1940. Plant microtechnique. Mc Graw-Hill, New York.

JONES, L.H.P. \& K.A. HANDRECK. 1967. Silica in soils, plants, and animals. Adv. Agron. 19: 107-149.

LABOURIAU, L.G. 1983. Phytolith work in Brazil: a minireview. Phytolitharien Newsletter 2: 6-10.

LOWENSTAM, H.A.1981. Minerals formed by organisms. Science 211: 1126-1131.

MA, J.F. \& E.TAKAHASHI. 2002. Soil, fertilizer, and plant silicon research in Japan. Elsevier, Amsterdam, The Netherlands.

MADELLA, M., A. ALEXANDRE \& T. BALL. 2005. International code for phytolith nomenclature 1_0. Ann. Bot. 96: 253-260.

MASSEY, F.P., A.R. ENNOS \& S.E. HARTLEY. 2007. Herbivore specific induction of silica-based plant defences. Oecologia 152: 677-683.

MEHRA, P.N. \& O.P. SHARMA. 1965. Epidermal silica cells in the Cyperaceae. Bot. Gaz. 126: 53-58.

METCALFE, C.R.1971. Anatomy of monocotyledons. $V$. Cyperaceae. Clarendon Press. Oxford.

MIRETZKY P., V. CONZONNO, A. FERNÁNDEZ CIRELLI. 2001. Geochemical mechanism controlling pampasic ponds hydrochemistry: Salado River drainage basin, Argentina. Rev. Bras. Recursos Hidricos 6: 29-39.

MIRETZKY, P., N.I. MAIDANA \& A. FERNÁNDEZ CIRELLI. 2002. Stability of diatom composition in a variable lake environment: Lake Chascomús, Argentina. Limnology 3: 77-85.

MOTOMURA, H., T. FUJII \& M. SUZUKI. 2000. Distribution of silicified cells in the leaf blades of Pleioblastus chino (Franchet et Savatier) Makino (Bambusoideae). Ann. Bot. 85: 751-757.
MOTOMURA, H., N. MITA \& M. SUZUKI. 2002. Silica accumulation in long-lived leaves of Sasa veitchii (Carriere) Rehder (Poaceae: Bambusoideae). Ann. Bot. 90: 149-152.

MOTOMURA, H., T. FUJII \& M. SUZUKI. 2004. Silica deposition in relation to ageing of leaf tissues in Sasa veitchii (Carriere) Rehder (Poaceae: Bambusoideae). Ann. Bot. 93: 235-248.

MOTOMURA, H., T. FUJI \& M. SUZUKI. 2006. Silica deposition in abaxial epidermis before the opening of leaf blades of Pleioblastus chino (Poaceae, Bambusoideae). Ann. Bot. 97: 513-519.

OLLENDORF, A.L. 1992. Toward a classification scheme of sedge (Cyperaceae) phytoliths. In RAPP G. y MULHOLLAND S.C. (eds.) Phytolith Systematics, pp. 91-111. Plenum Press: New York.

OSTERRIETH, M. 2004. Biominerales y Biomineralizaciones. In: GARCÍA CALDERÓN N. (ed.) Cristalografia de Suelos, pp. 206- 218. Sociedad Mexicana de Cristalografía. México.

OSTERRIETH, M., F. ALVAREZ, M. FERNÁNDEZ HONAINE, N. BORRELLI. 2012. Evolución pedológica en canteras ortocuarcíticas del área periurbana de Mar del Plata. In: DEL RÍO J.L. \& S.G. DE MARCO (eds.) Minería en áreas periurbanas. Una aproximación multidimensional, pp. 63-81. Editorial Universidad Tecnológica Nacional, Buenos Aires, Argentina.

PIPERNO, D.R. 2006. Phytoliths: A Comprehensive Guide for Archaeologists and Paleoecologists. San Diego: AltaMira Press.

PRYCHID, C.J. \& P.J. RUDALL. 1999. Calcium oxalate crystals in monocotyledons: a review of their structure and systematics. Ann. Bot. 84: 725-739.

RAGONESE, A.M., E. R. GUAGLIANON \& C. DIZEO DE STRITTMATTER. 1984. Desarrollo del pericarpio con cuerpos de sílice de dos especies de Rhynchospora Vahl. (Cyperaceae). Darwiniana 25: 27-41.

ROSSI, J.B. \& N.M. TUR. 1976. Autoecología de Scirpus californicus. II. Desarrollo del rizoma. Bol. Soc. Argent. Bot. 17: 280-288.

SANGSTER, A.G. 1970. Intracellular silica deposition in mature and senescent leaves of Siegliengia decumbens (L.) Bernh. Ann. Bot. 34: 557-570.

SANGSTER, A.G. \& D.W. PARRY. 1971. Silica deposition in the grass leaf in relation to transpiration and the effect of dinitrophenol. Ann. Bot. 35: 667-677.

SCHUYLER, A.E. 1971.Scanning electron microscopy of achene epidermis in species of Scirpus (Cyperaceae) and related genera. Proc. Acad. Nat. Sci. Phil. 123: 29-52.

STRUYF, E., S. VAN DAMME, B. GRIBSHOLT \& P. MEIRE.2005. Biogenic silica in freshwater 


\section{Fernández Honaine et al. - Amorphous silica biomineralizations in Schoenoplectus}

marsh sediments and vegetation (Schelde estuary, Belgium). Mar. Ecol. Prog. Series 303: 51-60.

STRUYF, E., S. VAN DAMME, B. GRIBSHOLT, K. BAL, O. BEAUCHARD, J.J. MIDDELBURG, P. MEIRE. 2007. Phragmites australis and silica cycling in tidal wetlands. Aquatic Bot. 87: 134-140.

TAIZ, L. \& E. ZEIGER. 2002. Plant Physiology. Sinauer Associates $3^{\text {rd }}$ Edition.

TREGUER, P., D.M. NELSON, A.J. VAN BENNEKOM, D.J. DE-MASTER, A. LEYNAERT \& B. QUEGUINER. 1995. The silica balance in the world ocean: a re-estimate. Science 268: 375-379.

TUR, N.M. \& J.B. ROSSI. 1976. Autoecología de Scirpus californicus. I. Crecimiento y desarrollo de la parte aérea. Bol. Soc. Argent. Bot. 17: 73-82.

WILCZEK, E. 1892. Beiträge zur Kenntniss des Baues der Frucht und des Samensder Cyperaceen. Bot. Centralblatt 51: 129-138, 193-201.

YAMAJI, N.; MITATNI, N. \& MA, J. F. 2008. A transporter regulating silicon distribution in rice shoots. Plant Cell 20: 1381-1389.

ZAR, J.H. 1984. Biostatistical analysis. Prentice-Hall, Englewood Cliffs, NJ, USA.

Recibido el 4 de marzo de 2012, aceptado el 6 de mayo de 2012. 
